\title{
On the Navigating between Anchored Ships and its Maneuvering Difficulty
}

Kinzo INOUE and Hideo USUI

\begin{abstract}
When the anchorages are arranged at a harbour, it is neccessary to consider the maneuvering difficulty of the navigating ship between the anchored ships. However, nobody has researched how design the arrangement of the anchorages from the view point of the maneuvering difficulty up to now.

In the present paper, the relationship between the condition of the arrangement of anchorages and the maneuvering difficulty has systematically analyzed by applying the Environmental Stress Model for the problems of the navigating ship between the anchored ships. Based on this analysis, the way to fix quantifalively the design elements of the arrangement of anchorages under condition that the maneuvering difficulty comes to an allowable level for mariners was considered. And, the distance needed between the anchored ships has been proposed on the basis of the diagram in acoordance with the length of navigating ship and the mean length of anchored ships.
\end{abstract}

\section{1.はじめに}

船舶が入港する際、バース待ちや沖荷役のために指定された錨地に投錨、錨泊することをしばしば経験 する。このとき船混みの激しい港では、予定錨地に接近する際にすでに錨泊している船舶の間を縫つて航 行することを余儀なくさせられることがある。船舶が複数の錨泊船の間を縫って航行するとき、錨泊船と 錨泊船の間の水域空間が狭くなるほど操船は困難となり、操船者には緊張がもたらされる。このようなと き、先に停泊している錨泊船の配置の状沉がどのようであれば、操船者にもたらされる困難性がどれほど になるかについては、これまでのところその関連性を定量的に明らかにした研究例はみあたらない。

著者はこれまでに、船舶が航行する水域空間が護岸や防波堤、浮標や錨泊船、操業漁船や漁網などの障 害物で制約されるとき、操船者にどれほどの負荷が課されるかを定量的に評価する手法として環境ストレ スモデル(1)を提案している。この評価モデルは、操船水域の空間的制約が操船者に課す負荷をストレス值を 指標として定量評価するものであり、ストレス值がどれほどにまで大きくなると操船者にとって許容でき なくなるかといった、指標値と許容可否基準の対応がついたモデルであるといら特徴を有している。

そこで、本研究では、錨泊船間航行の問題に環境ストレスモデルを適用し、錨泊船の配置の状況とこれ ら鈿泊船の間を航行する際に操船者に課される困難性の関係を系統的に分析するとともに、この分析を通 じて、錨泊船の間を縫って航行する際、操船者に課される困難性を許容範囲におさえることができること を条件として、錨地配置の設計要素の定量化を試みた。

* 正会員 神戸商船大学（产658-0022 神戸市東灘区深江南町5-1-1）

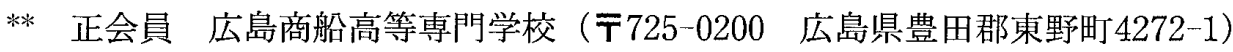




\section{2. 錨泊地の設計要素}

図 1 は、一定の広さの水域に複数の船舶が錨泊する場合の錨 地の配置の一例を示している。このとき、(1)それぞれの鈿地の 大きさ、(2)錨地と錨地の中心間距離、(3) 2 つの錨地を結ぶ線と その間を通過する船の針路交角、(4)錨地と航路の離隔距離、(5) 錨地と防波堤等との離隔距離、はそれぞれ錨泊地の設計要素を 構成する。

(1)、(4)、(5)の要素は基本的には振れ回りや走錨等の面から検 討すべきものと考えられ、これらの設計要素の検討は次の機会 に譲り、この研究では(2)、(3)の要素に着目し、操船面から望ま しい配置条件について考察する。検討にあたっては、まず相隣

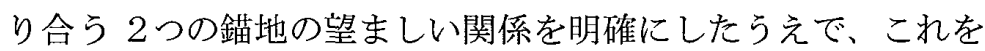
基本として複数の錨地の配置について考察を加える。

\section{3. 計算条件}

\section{1 船体条件}

一連の計算を行うにあたっては、航行船、鈿泊船ともに代表 的なものとして、全長 $130 \mathrm{~m}, 200 \mathrm{~m}, 280 \mathrm{~m}$ の 3 船型を想定した。 以下では $130 \mathrm{~m} 「 \mathrm{~S}\lrcorner 200 \mathrm{~m} 「 \mathrm{M}\lrcorner 280 \mathrm{~m} 「 \mathrm{~L}\lrcorner$ とする。

また、環境ストレスモデルによりストレス值を算出する際に 総トン数が必要となるが、これには「港湾の施設の技術上の基準 ・同解説」(2)に示されている貨物船、コンテナ船、タンカーの全 長と重量トン数との関係及び重量トン数から総トン数に換算す る関係式より、全長から総トン数を推定する回帰式を以下のよ うに得た。

$\log ($ 総トン数 $)=3.11 \times \log ($ 全長 $)-2.85$

(相関係数: 0.996)

以下、この回帰式をもとに全長から総トン数を推定し、スト レス值の計算に用いた。また、いずれの場合においても、航行 船の速力は 6 ノット一定とし、海域はオープンシーとした。

\section{2 錨泊船の配置}

\section{2 .1 . 2 隻の場合}

錨泊船功 2 隻の場合には図 2 に示す座標系を用いる。一般に障害物の至近を通航するとき、操船者はそ の障害物に対して一定の離隔距離を確保しようとする。操船者が錨泊船の付近を航行する際にこれ以上近 づきたくないという離隔距離については、「離隔距離 $=0.89 \times$ 航行船の全長」 ${ }^{(3)}$ なる関係式が得られてい る。そこで、ストレス值の計算にあたっては、物理的な衝突ではないものの、錨泊船の中心から錨泊船の 周囲に下記の式で示される距離を半径 $r(\mathrm{~m})$ とするバリアがあるものとして計算を行った。

$$
\text { 半径 }(\mathrm{m})=0.89 \times \text { 航行船の全長 }(\mathrm{m})+0.5 \times \text { 錨泊船の全長 }(\mathrm{m})
$$

針路交角 $(\theta)$ については航行船の針路と錨地を結ぶ線が直交する場合を 0 度とし、左回りを正とする。 また、錨泊船間距離 $(l)$ については、2 隻の鈿泊船の中心点間の距離をとる。

\section{2 .23 隻の場合}

錨泊船が 3 隻の場合に用いる座標系を図 3 に示す。航行船の針路にship 1 とship 2 を結ぶ線が直交し、 ship 3 が航行船の針路上に存在する 2 等辺三角形を基本の配置として考える。このとき、ship 1 とship 2 を結ぶ線とship 1 とship 3 を結ぶ線がなす角を底角 $\alpha$ とする。なお、 2 等辺三角形の高さ $d$ は後方錨泊船 までの距離に対応する。 


\section{4. 操船困難性の検討と錨泊地設計要素の定量化}

\subsection{2 隻の錨泊船間航行}

\section{1 .1 大きさが同じ場合}

$\theta=0$ の条件の下で、ship 0 がship 1 とship 2 を結ぶ線の中 央を通過するとき、 2 隻の錨泊船の存在がship 0 に課す操船上 の困難さを環境ストレスモデルを適用して求めた結果を図 4 に 例示する。この計算に際しては、ship $0, \operatorname{ship~} 1, \operatorname{ship} 2$ とも $\mathrm{M}$ (長さ $200 \mathrm{~m}$ ) とし、ship 1 とship 2 の錨泊船間距離を $600 \mathrm{~m}$, $800 \mathrm{~m} ， 1,000 \mathrm{~m} ， 1,200 \mathrm{~m}$ とした。図 4 より、錨泊船間距離が長 くなるに伴いストレス値のピークが低くなること、また、スト レス值がピークとなるのは 2 隻の錨泊船間を結ぶ線上に航行船 が並ぶ直前であり、錨泊船間距離が変化してもその位置はほぼ 一定であることが分かる。

環境ストレスモデルから出力される操船環境ストレス值は操 船水域を制約する環境条件が操船者に課す操船上の困難感を定 量的に表現するものである。そして、その值が500以下であれば 全ての運航実務者がその状況を許容し、750では全体の $1 / 40$ 運航実務者が許容できない状況に対応し、そして、900では全体 の $3 / 4$ の運航実務者が許容できない状沉であり、これを超え た場合にはもはや全ての運航実務者が許容できないといった基 準と対応ゔけられている。

錨地設計の観点からは、錨泊船間航行が操船者に課す困難性 は、全ての運航実務者にとって許容できるものであることが望 まれる。そのため、ここでは運航実務者にとって課される負荷 が”negrigible”である環境ストレス值500の值を基準として必 要とされる設計要素のあり方を考える。

操船環境ストレス值が500 となるような錨泊船間距離は図 4 から、2 隻の錨泊船間を通過する際の操船環境ストレス值の変 化に掠ててそのピークがちょうど500となるような錨泊船間距 離を求めればよい。

図 5 は、2 隻の錨泊船が同じ大きさの場合に、ストレス值が 500 となる錨泊船間距離を縱軸に、錨泊船の大きさを横軸に、そ して、航行船の大きさをパラメータとしてプロットしたもので ある。

例えば 2 隻の錨泊船をS(長さ $130 \mathrm{~m}$ )一定とした場合におい て、航行船がSの場合は所要の錨泊船間距離が $600 \mathrm{~m}$ 、航行船が $\mathrm{M}$ (長さ $200 \mathrm{~m}$ ) の場合は $800 \mathrm{~m}$ 、航行船が $\mathrm{L}$ (長さ $280 \mathrm{~m}$ ) の場合は 1,000m となる。このように 2 隻の錯泊船の間を通過しようとす る航行船の船型が大きくなるほど 2 隻の錨泊船間距離は広く必 要とされる。また、例えば航行船をS(長さ $130 \mathrm{~m}$ )一定とした場 合において、2 隻の錨泊船がS（長さ $130 \mathrm{~m}$ )の場合は所要の錨泊 船間距離は $600 \mathrm{~m} 、 2$ 隻の錨泊船が $\mathrm{M}$ (長さ $200 \mathrm{~m}$ ) の場合は $700 \mathrm{~m} 、 2$ 隻の鈿泊船がL (長さ $280 \mathrm{~m}$ ) の場合は $800 \mathrm{~m}$ となるよう

に、錨泊船が大型船であるほど必要な錨泊船間距離は長くなる。このように、必要な錨泊船間距離は航行 船の大きさと錨泊船の大きさの両者に依存する。そこで、同じ大きさの 2 隻の錨泊船間航行に対し、航行 船の全長及び錨泊船の全長を説明変数とし、所要の錨泊船間距離を被説明変数として重回帰分析を適用す

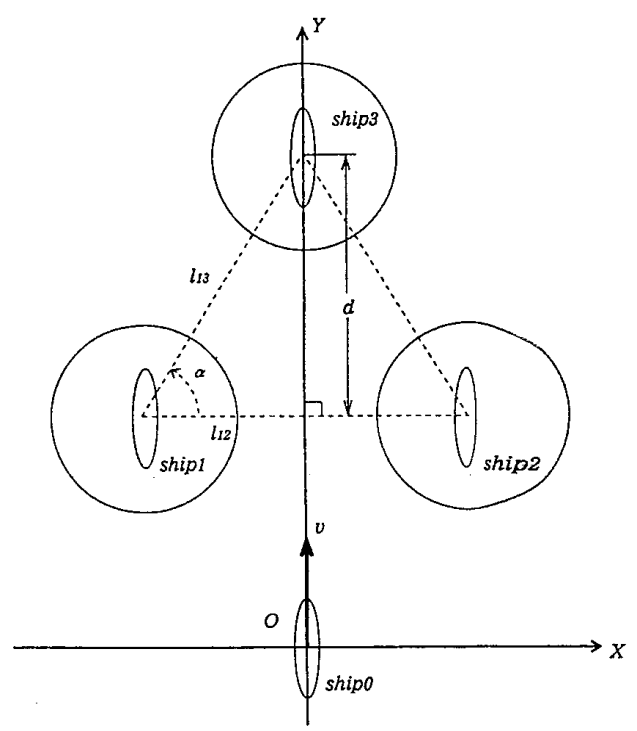

図 3 錨泊船 3 隻の場合の座標系

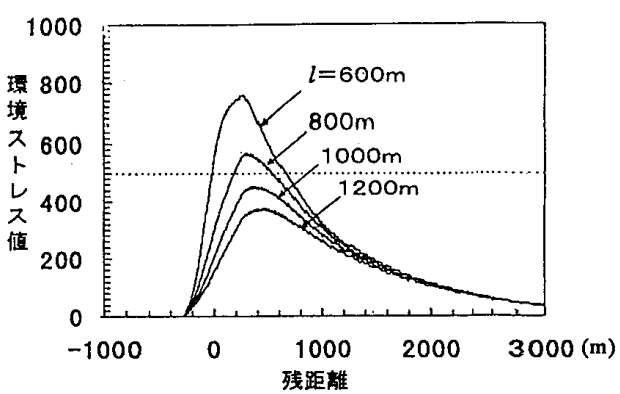

図 4 錨泊船 2 隻の場合のストレス値 の変化

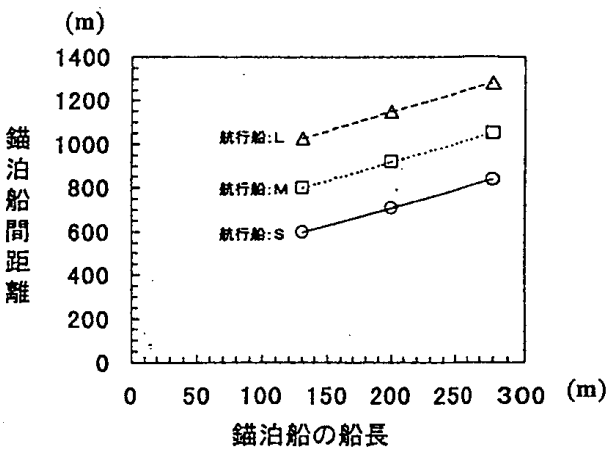

図 5 大きさの同じ 2 隻の錨泊船の場 合の必要錨泊船間距離 
ると、次式を得る。

錨泊船間距離 $=2.91 \times$ 航行船の全長 $+1.64 \times$ 錨泊船の船長 +5.0

(重相関係数: 0.9999)

この回帰式を用いることにより、同じ大きさの 2 隻の錨泊船の間を任意の大きさの航行船が通過すると きに必要とされる錨泊船間距離が得られる。

4.1 .2 大きさが異なる場合

隣り合う 2 隻の錨泊船が同じ大きさであれば、一般に操船者は 2 隻の錨泊船の中央を航行すると考えら れるが、2 隻の錨泊船の大きさが異なる場合は操船者の意識として小さい錨泊船側に近寄って航行すると 考えられる。このような時にはそれぞれの錨泊船から与えられる困難性が等しくなるようにコースを選択 することが予想される。そこでここでは、大きさが異なる 2 隻 の鈿泊船間航行に際してはそれぞれの錨泊船が単独で存在した と考えた場合のそれぞれの船が課す操船環境ストレス值が等し くなるようなライン上を通航するものとして、2 隻の錨泊船の 中央かュら小さ錨泊船側に近寄る方向にコースラインを偏位さ せることとした。なお、コースラインが今回設定したライン上 でなくても、今回設定したラインから左右 $50 \mathrm{~m}$ 程度の範囲にあ れば、操船者に課される困難性はほとんど変らない。

2 隻の錨泊船が異なる大きさの場合について、錨泊船間を航 行中に課される最大のストレス值が500となるような錨泊船間 距離を、2隻の錨泊船と航行船がL，M，Sのあらゆる組み合わ せについて求め、その結果ををとめたものを図 6 に示す。この 結果にはすでに4.1.1項で分析した 2 隻の錨泊船が同じ大きさ

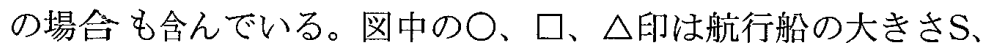
$\mathrm{M} 、 \mathrm{~L}$ の分類をあらわし、図の横軸は 2 隻の錨泊船の全長の平均 をとつている。ここに、航行船の全長及び錨泊船の平均長さを 説明変数とし、錨泊船間距離を被説明変数として重回帰分析を 適用すると、次式を得る。

錨泊船間距離 $=2.92 \times$ 航行船の全長 +1.64

(重相関係数 : 0.9999)

$$
\text { ×錨泊船の平均 長さ }+0.89
$$

この回帰式により、2 隻の錨泊船および航行船の任意の大き さの組み合わせに対して必要とされる錨泊船間距離を求めるこ とが可能となる。

図 7 は(4.2)式の回帰式をもとに航行船の全長を横軸に、錨泊 船の平均長さを縦軸としてダイヤグラムの形で整理したもので ある。例光ば航行船がMの場合において錨泊船の組み合わせが LとSであれば錨泊船間距離は $900 \mathrm{~m}$ 必要となることがこの図か ら読み取れる。今後、錨地の配置設計を行う場合、想定される 航行船と錨泊船の組み合わせごとに必要となる 2 つの錨地間の 距離を算定するのにこの式とダイヤグラムが役に立つ。

\section{1 .3 針路交角}

図 8 は、航行船及び 2 隻の錨泊船の大きさをすべてM、錨泊 船間距離を $1,000 \mathrm{~m} 、 \theta$ を $0 ， 10 ， 20 ， 30 ， 40 ， 50$ 度として、2 隻の錨泊船が航行船のルートに対し斜めに配置されるとき、操 船者に課される負荷の変化傾向を求めたものである。これによ ると針路交角が 0 度では 2 隻の錨泊船は一体のものとして認識 され、2隻の錨泊船の間を通過する際にストレス值のピークが

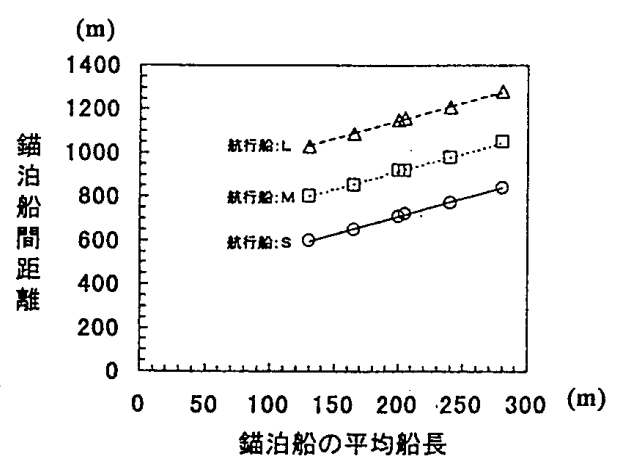

図 6 大きさの異なる 2 隻の錨泊船の 場合の必要錨泊船間距離

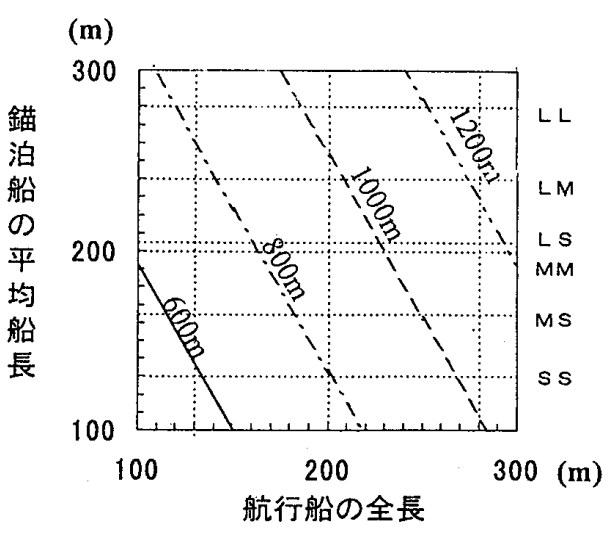

図 $7 \quad 2$ 隻の錨泊船間の必要距離

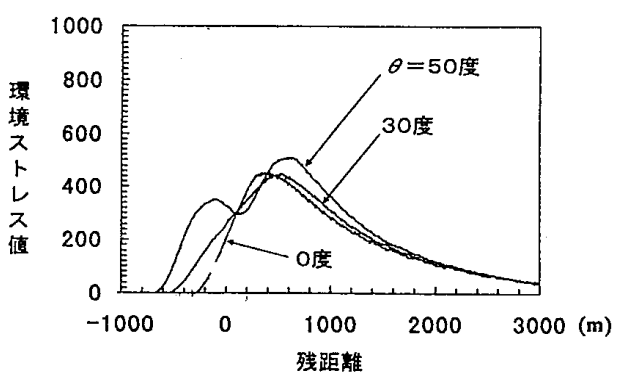

図 8 錨泊船 2 隻の場合の針路交角の 影響 
1 回現れる形の負荷が課される。針路交角が30度程度までは同 椂の傾向を示し、1 回のストレス值のピークの高さはほぼ一定 である。しかし、針路交角が30度を超えると、2 隻の錨泊船は 1 隻ずつ分離して操船者に負荷を課すようになりピークが $2 つ$ に分かれるとともにピークの高さが増加するようになる。

図 9 は、針路交角が大きくなる時、2隻の錨泊船間を通過す る際のストレス值のピークが500となるような錨泊船間距離を 釬路交角との関係からとりまとめたものである。針路交角が 30 度程度までは必要となる錨泊船間距離は 2 隻の錨泊船が航行船 の針路に対し直角に配置される場合に必要とされる距離と同じ であるが、針路交角が30度を超えると必要とされる錨泊船間距 離が急激に増加することがわかる。つまり、2つの錨地の配置 とその間を通過する船の針路との関係が 0 度土 30 度までの範囲 であれば、操船者に課す困難性の観点からは両者が直交する場 合々設計上同等とみなすことができる。

\subsection{3 隻の錨泊船間航行}

4.2 .1 大きさが同じ場合

図 3 に示した座標系において、ship 1 とship 2 の錨泊船間距 離 $l_{12}=1,200 \mathrm{~m}$ の条件の下で、後方錨泊船までの距離 $d$ を変化 させたときに、3 隻の錨泊船の存在が航行船ship 0 に課す操船 上の困難さを環境ストレスモデルを適用して求めた結果を図 10 に示す。なお、この時ship 0 はship 1 とship 2 を結ぶ線の中央 を通過することとした。また、ship 0, ship 1, ship 2, ship 3 ともすべて同型の $\mathrm{M}($ 長さ $200 \mathrm{~m})$ として計算した。

ストレス值はship 1 とship 2 にほぼ並ぶ地点で一度ピーク

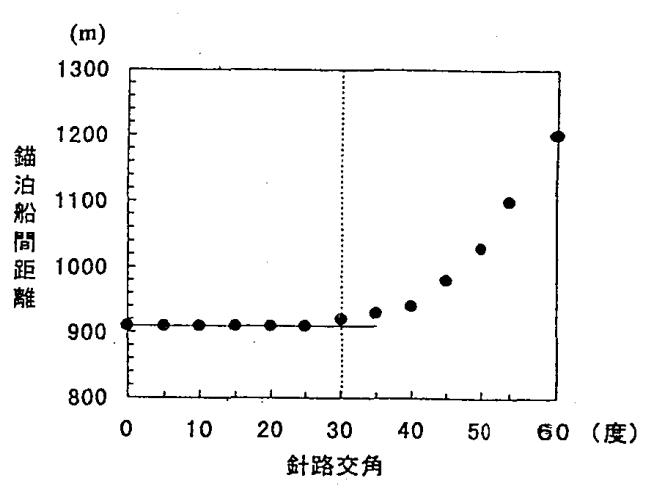

図 9 錨泊船 2 隻の場合の針路交角に よる必要錨泊船間距離の変化

を迎え、その後は減少するものの、後方のship 3 に近づくにつれて再度増加傾向を示すようになる。ただ し、ship 3 を置く位置、つまり距離 $d$ を遠くするに伴い、ストレス值のピークは減少傾向を示す。ここに $d=$ $1,200 \mathrm{~m} 、 1,400 \mathrm{~m} 、 1,600 \mathrm{~m}$ の曲線に着目すると、このようにdをある一定の距離以上に離してもストレス

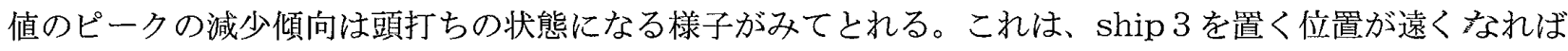
操船者に与える困難性は全体として減少するものの、ship 3 を置く位置がある距離以上遠くであれば、そ れ以上離してもストレス值のピークの值の減少に関してはほとんど効果が変わらないことを意味する。

そこで、この困難性がほとんど変わらなくなる位置にship 3 を置くことを 3 隻目の錨泊船配置の条件と 考える。その上で手前 2 隻の錨泊船を含む合計 3 隻の錨泊船配置との関係から、航行中にship 0 に課され るストレス值のピーク值が 500 となるような手前 2 隻の錨泊船間距離 $l_{12}$ と 3 隻目の錨泊船の位置 $d$ を求め る。このようにして、錨泊船が 3 隻の場合の配置条件を決める。この考え方のもとで錨泊船が 3 隻共同じ 大きさの場合について手前 2 隻の錨泊船間距離 $l_{12}$ を求めたところ、4.1項で述べたように同じ大きさの 2 隻の錨泊船の間を通過する時に必要とされる錨泊船間距離に比べて、概ね 1.3 倍程度の間口の広さが必要と なることがわかった。

次に、後方錨泊船ship 3 までの距離 $d$ と手前 2 隻の錨泊船間距離 $l_{12}$ の関係から底角 $\alpha$ を求めたところ、 概ね60度となり、錨泊船が 3 隻でかつそれらが同じ大きさの場合、そこを通過する航行船の操船者に困難 を課さない 3 隻の配置条件はほぼ正三角形と考えてよさそうである。

\section{2 .2 大きさが異なる場合}

航行船及び 3 隻の錯泊船の大きさがL、M、Sのあらゆる組み合わせについて前項に述べたと同じ考え方 のもとで、手前 2 隻の錨泊船間の所要の間口の広さ $l_{12}$ および底角 $\alpha$ を求めた。図 11 は、錨泊船が 2 隻の場 合に必要とされる錨泊船間距離を基準に 3 隻の場合にはどれくらい広く必要となるかを比率をとって示し ている。これらの計算には 3 隻の錨泊船がそれぞれ同じ大きさの場合む含んでいる。航行船が大きいほど その比率が大きくなるものの、概ね 1.3 程度であることがわかる。このことから、3 隻の錨泊船を配置する 
場合に必要とされる

錨泊船間距離 $l_{12}$ は、 2 隻の錨泊船の場合 に必要とされる錨泊 船間距離を 1.3 倍す ることによって求め ることが可能である といえる。

また、底角 $\alpha に つ$ いて注图12に示すよ うに、航行船が大型 船ほど底角は小さく なり、後方に配置さ

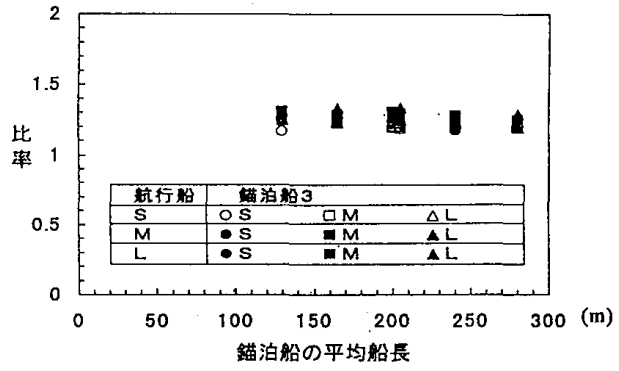

図11 錨泊船 2 隻の時の必要距離を基 準とした錨泊船 3 隻の場合の間 口の広さ れるship 3 が大型になると底角は大きくなり、手前 2 隻の錨泊 船の平均船長が長くなるほど底角が小さくなるといった傾向が 見られる。そこで、航行船ship 0 の全長、ship 3 の全長、及び ship 1 とship 2 の平均長さをそれぞれ説明変数とし、底角 $\alpha$ を 被説明変数として重回帰分析を適用すると次式を得る。

底角 $=-0.050 \times \operatorname{ship} 0$ の全長 $+0.015 \times \operatorname{ship} 3$ の全長 $-0.034 \times \operatorname{ship} 1$ とship 2 の平均長さ +78.679

(重相関係数 : 0.950)

この回㷌式により、任意の大きさの錨泊船の組み合わせにつ いて、それぞれの錨地を配置する際の底角が求まることとなり、 先に示した錨泊船間距離 $l_{12}$ とともに、これらの情報を用いるこ とにより錨地の配置形状を決定することが可能となる。

4.2 .3 錨泊船間航行と困難性の試算

3 隻の錨泊船の間を航行する際には、図13に示すように手前 2 隻の錨泊船を航過した後どこか適当な位置で次の針路に変針 することが必要となる。この場合の変針点をどこに設定すべき かについては、手前 2 隻の錨泊船を航過した後、後方の錨泊船 に対する困難性が操船者にとって許容できる範囲にある間のど こか、すなわちストレス值が500を超えない間のどこかの地点に 变針点を設定することが妥当であるう。ここでは、各錯泊船を 結ぶ線と直交するようにコースラインを設定した場合を考え る。この時の変針点は幾何学的に見れば外心点」ということに なる。

この外心点を変針点とするよらなコースライン上を航行して 錨泊船間を通過する間のストレス值の変化を図14に示す。航行 船をL、錨泊船を $\mathrm{S} ， \mathrm{~L} ， \mathrm{~L}$ とした条件は操船上の困難性がさまざ まな組み合わせの中でもっとも高いケースであり、航行船をS、 錨泊船を $\mathrm{S}, \mathrm{S}, \mathrm{L}$ とした条件は操船上の困難性がもっとも低いケ 一スである。また、航行船をM、錨泊船をS，L，Mとした条件 はその中間にある条件のひとつである。いずれのケースにおい ても、ship 1 及びship 2 を結ぶ線に並ぶ付近でストレス值はピ 一クとなるが、その後、後方のship 3 に接近するためにストレ

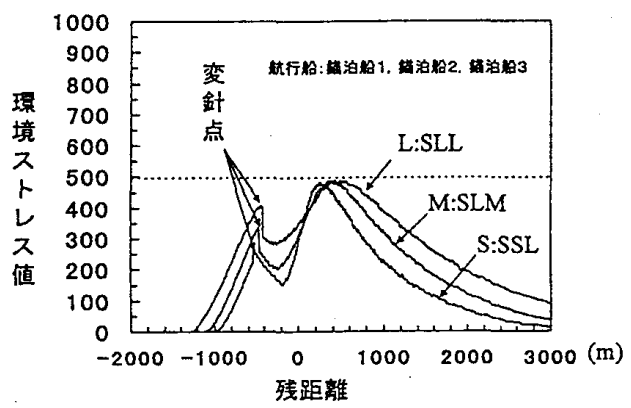

図14＼cjkstart外心点で変針した場合のストレ 又值の変化

ス值は再度ピークに向からものの、その上昇途中で変針を行うこととなる。変針する手前まではship 3 に 対する困難性が対象であったものが、変針後はship 2 及びship 3 が困難性の対象となるため、変針直後に 
ストレス值は一旦大きくなるものの、その大きさは操船者にと って許容できる500以下に执さまっている。このことより、手前 2 隻の鈿泊船を結ぶ線に直交して航行し、外心点を变針点とし たコースライン上を航行する時は、これらの錨泊船間を航行す る際に操船者に余分の負荷をかけないこととなり、今回提案し た錨地のディメンジョンと配置に関する設計の考え方の妥当性 を示すものである。

さらに、変針をせずに 3 隻の錨泊船間を直線的に航行する場 合も考えられる。図13に示した点 $a 、 b$ 各錨泊船を結ぶ線の 2 等分点であるが、この $a 、 b 2$ 点を直接結ぶ線をコースラインと した場合のストレス值の変化を図15に示す。航行船の組み合わ せは、図14の計算と同様に、操船上の困難性がさまざまな組み 合わせの中でもっとも高いケースともっとも低いケース、およ びその中間のケースをとっている。いずれのケースに执いてす、 ストレス值の大きさは操船者にとって許容できる500以下にお さまっている。

また、 $a ， b$ 点を結ぶコースラインを中心にして、 $a$ 点を通る という条件の下で針路が左右に偏する場合のストレス值の変化 も求めたところ、錨泊船の大きさのどのような組み合わせの場 合もその偏りが士15度程度の範囲までならストレス值は500以 下におさまる。このことから、手前 2 隻の錨泊船ship 1 とship 2 の中点 $a$ 、およびship 3 とship 2 の中点 $b$ を結ぶ線をコース ラインとして航行する時、今回提案した錨地設計の考え方は土 15度以内のコースのずれに対してまで航行時の誤差を許容でき るといえる。

\section{3 航行船の速力}

ここまで航行船の速力はいずれの場合においても 6 ノットと してきた。しかしながら、実際にはそれ以上の速力の場合も想 定される。このため、速力を $6 、 8 、 10$ ノットとして速力によ るストレス值への影響について検討したところ、錨泊船が 2 隻 の場合も、錨泊船が 3 隻の場合も、6ノットに比べ $8 、 10 / ッ$ 卜となるほど錨泊船までの距離が遠い位置からストレス值がや や高くなるもののピークとなる付近での值にはほとんど差はな いとみてよいことがわかった。

\section{5. 錨地の配置設計の例}

錨地の配置設計をする際の要素として、ここでは錨泊船間距 離 $l_{12}$ と底角 $\alpha$ 亿着目し、操船困難性の面からその定量化につい て検討を行った。その結果、同じ大きさの錨泊船の組み合わせ で航行船がLの場合には、図16に示すようにその形状は正三角 形で、錯泊船が小型になると相似のまま各辺の長さが短くなる。

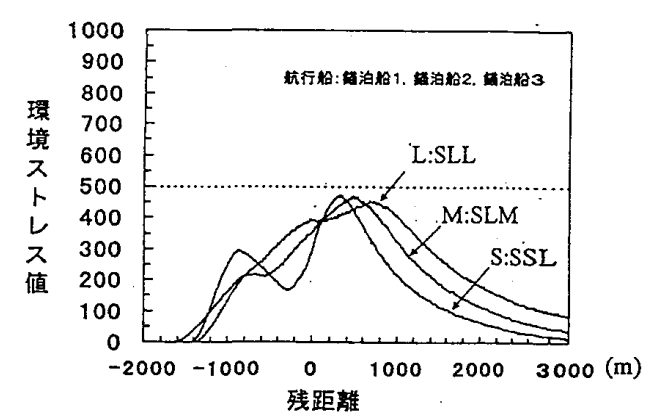

図15２等分点を結ぶ線上を航行する 場合のストレス值の変化

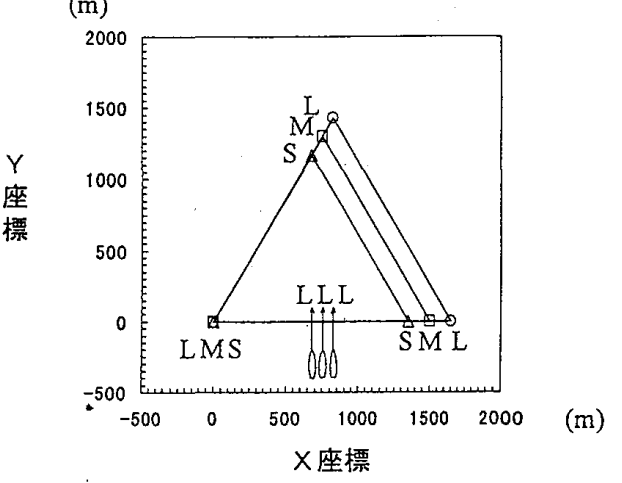

図16＼cjkstart錨泊船の配置例(航行船をLとし て、錨泊船が同じ大きさの場合）

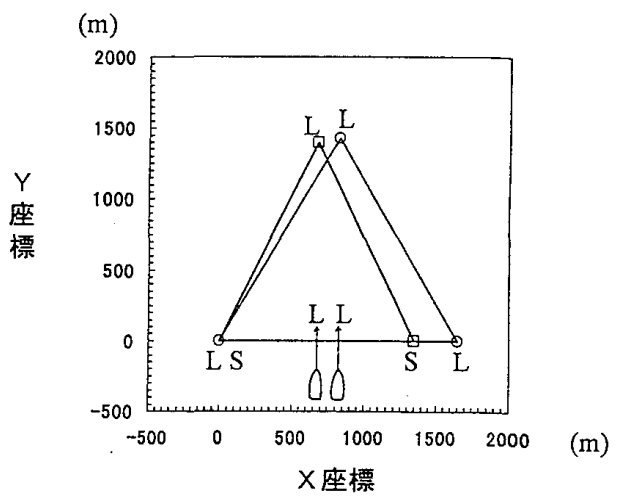

図17＼cjkstart錨泊船の配置例(航行船をLとし て、錨泊船が異なる大きさの場 合) しかしながら、航行船がLの場合でも錨泊船の大きさがそれぞ れ異なる場合には、図17に示すように正三角形ではなく、(4.3)式の回帰式で与えられるような底角 $\alpha$ を有 する 2 等辺三角形になる。これらの図は三角形の面積が最も大きくなる場合と最も小さくなる条件を描い たものであり、錨泊船と航行船の大きさが L $(280 \mathrm{~m}) 、 \mathrm{M}(200 \mathrm{~m}) 、 \mathrm{~S}(130 \mathrm{~m})$ のバリエーションのもとでは 必要となる三角形の各辺の長さは概率 $1,300 〜 1,500 \mathrm{~m}$ となる。現状の港において錨地間の間隔が700〜 
1,000m程度であることと比べると、錨泊船間を航行する際に航行船の操船者に課される困難性の観点から 見ると、現状の錨泊船間距離澡船者にやや大きな困難性を課すようである。

\section{6. まとめ}

鈿泊船の間を縫って航行する際に操船者に与える困難性を環境ストレスモデルを適用して系統的に分析 を行った。その結果以下のような知見を得た。

(1) 2 隻分の錨地の配置設計に際しては、航行船の全長及び錨泊船の平均長さによって、錨泊船間距離を求 めることができる回帰式 (4.1) 式を得た。そして、利用時の便利さを考慮して、これをダイヤグラムの形 で提供した。

(2) 3 隻分の錨地の配置設計については、錨泊船間距離は、(1)に示した 2 隻の錨地の場合に必要とされる距 離の1.3倍となる。そして、3 隻を配置する時の形状は正三角形を基本とする二等辺三角形となり、その 底角は、(4.3)式の回帰式より求めることができる。

(3) 2 つの錨地の配置とそれに対する針路交角が士30度の範囲であれば操船者に課す困難性の観点からは直 交して航行する場合と設計上同等とみなせる。

\section{参 考 文 献}

（1）井上・増田・原・宮坂：操船者の危険感に基づく操船環境と交通環境の同時評価法，日本航海学会論 文集, 第 97 号, 平成 9 年 9 月.

（2） 日本港湾協会：港湾の施設の技術上の基準・同解説 改訂版，平成元年 2 月.

（3）井上・宇佐美・柴田：制約水域における航過距離と離隔距離に関する操船者意識のモデル化，日本航 海学会論文集, 第 90 号, 平成 6 年 3 月.

\section{質 疑 応 答}

及川 清：本研究は錨泊船の錨位選定の問題に視点をおいたすのでしょうか。それとも鈿泊船間の水域航 行船の安全に視点をおいたものでしょうか。その何れに視点をおいて考えたらよいのでしょらか。

半英夫：基本的には後者に視点を置いています。ただし本研究では、航行船が錨泊船間を航行する際の 困難性を、航行船の立場から定量的に評価、検討を行い、その成果を基にして、これまで基準の定めの なかった港外における指定錨地などの配置設計の考え方を策定することを目的としています。

増井 眞(日本船長協会)：本船の大きさと船間距離を取り上げているが錨泊船の船首を通過するか船尾を 通過するかによって通過距離が同じでもストレス值が変わるのではないか。

臼井英夫：今回の計算では錨泊船の姿勢は考慮していません。その代わりに、航行船の操船者が侵入した くない限界距離しして錨泊船の周囲に円形のバリアを設定して計算しました。

野村士平 (弓削商船高等専門学校)：角度をもった時の 2 船間のストレス值は、単純に有效航過巾(すなわち 交角を $\theta$ とした時の 2 船距離 $\times \sin \theta)$ として幾何学的な関係から求めることは出来ないか。

臼井英夫：環境ストレスモデルにおける操船環境ストレス值は、錨泊船と航行船との距離及び航行船の速 力から求められる鈿泊船に衝突するまでの余裕時間により算出される危険度をあらわすSJL值を、航行 船の針路に対して \pm 90 度の範囲で 1 度毎に求め、これを積算することによって計算されます。そのため、 航行船が同じ位置から錨泊船を見た場合において、針路交角 $\theta$ が変われば錨泊船までの距離が異なりま すので、結果として計算されるストレス值も異なってきます。従いまして、単純に有効航過巾のみによ る幾何学的な関係からは求めることはできず、航行船と錨泊船との位置関係からそれぞれ求める必要が あります。 